ISA

Arboriculture \& Urban Forestry 2018. 44(1):12-22

\title{
Assessment of Six Indicators of Street Tree Establishment in Melbourne, Australia
}

\author{
M. Leers, G.M. Moore, and P.B. May
}

\begin{abstract}
A number of factors can influence successful street tree establishment, including inappropriate selection of stock, poorquality stock, poor planting technique, insufficient irrigation, poor weed control, and inadequate maintenance. Urban tree managers need reliable, accurate, and practical indicators of whether street trees have successfully established to inform decisions about removing supporting stakes or continuing irrigation regimes. The establishment of street trees planted as large format stock was investigated using a survey of 510 trees from 21 species managed by three municipalities in Greater Melbourne, Australia.

A planted tree can only be considered established when the partial root system in the root ball or the confined root system in a container has developed into a spreading root system, utilizing moisture and available nutrients throughout a larger soil volume. Thus, an indicator of root expansion into soil of a greater volume is necessary, as are measures of canopy growth, such as shoot-tip growth or canopy dieback. The survey assessed six factors indicative of successful or poor establishment: whether trees had been planted too deeply, whether trees exhibited trunk movement at or below the soil surface, damage to the trunk, trunk sunscald injury, presence of epicormic shoots on the trunk, and whether there were co-dominant stems.

The results demonstrated that trunk damage $(8 \%)$ and codominant stems (5\%) occurred at low rates in the trees, but the presence of epicormic shoots (12\%) and sunscald damage (12.5\%) was more common, and $12 \%$ of trees had been planted too deeply and $42 \%$ of trees were unstable. Three criteria-shoot tip extension, trunk movement in the ground, and percentage of canopy dieback-provided useful measures of whether street trees were assessed as being well- or poorly-established. This is the first study to record a high incidence of sunscald injury to urban trees in Australia.

Key Words. Australia; Melbourne; Shoot-Tip Extension; Sunscald; Tree Stability; Trunk Movement; Urban Forestry.
\end{abstract}

A number of factors can influence successful street tree establishment, including inappropriate selection of stock, low-quality stock, poor planting technique, insufficient irrigation, lax weed control, and inadequate maintenance (Watson 1987; Ward et al. 2000; Gilman et al. 2010; Kenney et al. 2011). The effectiveness of street tree planting may be determined by whether the individual trees have established and by their long-term performance (Bühler et al. 2007). While the term tree establishment is commonly used by urban tree managers, its meaning is rarely defined. Some researchers have used the term to indicate that newly planted trees have shown canopy growth, which may be measured as height increment (Sinnett al. 2008) or a combination of caliper, height, and crown spread (Day et al. 2009; Gilman et al. 2010). Others have included measures of root spread and root growth (Sinnett et al. 2008; Gil- man et al. 2010), and some have simply recorded whether trees have survived (Day et al. 2009), or have measured tree vitality using shoot growth and the health of canopy tissues (Bühler et al. 2007).

The first few years immediately after transplant are critical to establishment and it is during this time that factors influencing establishment have the most profound effect (Watson 1992). There are opportunities for improved street tree management by evaluating establishment and predicting potential success (Struve 1993; Day et al. 2009; Gilman et al. 2010). Urban tree managers also need reliable, accurate and practical indicators of whether street trees have successfully established to inform decisions about removal of supporting stakes, whether irrigation regimes should be continued for recently planted trees, and whether poorperforming trees should be removed and replaced. 
Tree establishment and the level of performance are different components of street tree growth. Tree establishment relates to the extension of the root system of the recently planted tree into the backfill soil that stabilizes it in the ground and increases the volume of resources available to the tree (Sinnett et al. 2008; Gilman et al. 2010). Establishment also requires that the canopy has adequate health, structure, and growth to allow the subsequent successful growth of the street tree in the long term (Day et al. 2009; Gilman et al. 2010). Tree performance is assessed by how the tree grows within the landscape over time and is often characterized by measures such as growth rate, height increment, canopy spread and density, and measurements of girth increase. This paper investigates some of the patterns in the assessment of street tree establishment, which could prove useful in making future decisions about the management of the trees.

Nursery tree stock between two meters and four meters tall is described as advanced stock in the Australian horticultural industry, and the use of trees of this height as street tree planting stock is common in municipal planting in Australian cities. Advanced tree stock has the advantage over smaller planting stock of having an immediate impact on the streetscape, with success of up to 10 years, but their success in the longer term may be put at risk if they have poorly developed root systems (Moore 1997). When the one- to five-yearold tree is introduced to the urban landscape, it is more tolerant of changes in environmental conditions than it will ever be again (Whitcomb 1987). However, the success of the tree often depends upon species selection and site conditions (Struve 1993). Poor tree health can be an indicator of stress, and while Strouts and Winter (1994) note that symptoms do not usually provide an explanation of ill health in a tree, they may be indicative as to the possible causes of a problem. Common symptoms of tree problems associated with poor establishment include chlorotic foliage, leaf necrosis, canopy dieback, presence of epicormic shoots, and general health decline. Often, a single tree presents multiple symptoms (Harris et al. 1999).

Factors involved in assessing tree performance in urban environments should include size increase (height, trunk diameter, and canopy spread), crown condition and integrity, and tree health, which includes structural integrity and expected longevity (Harris et al. 1999; Day et al. 2009; Gilman et al. 2010). The tree also needs to have a well-developed root system, which not only has the capacity to supply sufficient water and nutrients for canopy growth, but firmly anchors the tree (Sinnett et al. 2008; Gilman et al 2010). Canopy dieback directly, and adversely, affects root growth because of reduced carbohydrates and growth regulators. Trees planted too deeply may exhibit good canopy growth (Moore 1985), but their prospects for successful establishment are compromised (Arnold et al. 2007; Day et al. 2009).

Trunk movement at ground level, often determined in Australia by the Burnley Method of testing tree stability and root establishment (Moore 1990), indicates poor stability due to a poorly established root system, especially outside the root ball. It is the root system that supplies water, nutrients, and growth regulators, ensuring healthy shoot growth (Kozlowski 1971; Patterson 1976; Watson 1992). The Burnley Method, which is a coarse field test of root establishment, involves pushing the trunk of a tree forward and back, by hand, at a height above the ground set by the size of the tree. The height at which the trunk is grasped is above $50 \%$ of the tree's height, and the trunk is moved through an arc of 600-1000 mm backwards and forwards and/or side-to-side, but with insufficient force to risk the snapping of the stem. When the trunk at ground level (as a fulcrum) appears to be moving below the soil surface, it suggests poor lateral root establishment (Moore 1990).

Damage to the stem of young trees and sunscald injury may affect successful tree establishment by disrupting transport between roots and canopy (Kozlowski et al. 1991; Roppolo and Miller 2001), which in turn may limit carbohydrate supply to the root system or water and nutrient supply to the canopy. Consequently, there may be poorer root or canopy establishment. Sunscald on the trunks of newly planted street trees, caused by high temperatures or water stress, may cause injury to trees and result in the death of bark tissue (Rushforth 1987; Kozlowski et al. 1991; Roppolo and Miller 2001). Kozlowski et al. (1991) refer to individual trees from forest stands displaying symptoms of sunscald after 
heavy thinning, resulting in reduced growth and death. When the vascular system is stressed and damaged, the result may be inhibited translocation and reduced uptake of water affecting growth.

Assessing canopy dieback is a common method of portraying canopy condition, but it more accurately depicts problems with canopy structure than canopy growth. It is possible that a tree exhibits canopy dieback, but at the same time, some branches grow well and have good foliage density. Measuring annual tip extension (the distance between the scale scars and the terminal bud) is a suitable method of quantifying top growth (Watson 1987; Watson et al. 1992). Such growth may then be used as an indicator of overall plant growth and establishment. There is a significant relationship between shoot growth and root regeneration after transplanting (Watson 1987; Grossnickle 2005). The presence of epicormic shoots in the canopy of young trees is an indicator that trees may be stressed, and the occurrence of codominant stems in young street trees suggests that they may perform badly as they mature, due to the tendency of co-dominant stemmed trees with included bark to be structurally weak and prone to splitting (Ryder and Moore 2013; Moore 2015).

In this paper, establishment is defined as the tree being of an acceptable height for its species and age, having a good canopy spread and density, and being stable in the ground for two growing seasons after planting. The assessment of establishment would be made by the municipal arborist or the responsible landscape architect in accordance with the local government agency's street tree specifications. It was anticipated that many trees would successfully establish within the first twelve months after planting, and others would do so within two growing seasons. However, trees that had been planted for longer periods, of up to 120 months, were also investigated to determine whether they had successfully established.

The aim of this study was to examine a number of measures that would provide accurate and practical indicators of successful tree establishment for urban tree managers by surveying street trees. The measures selected were chosen because they are non-destructive of the trees and also because data could be collected effectively and efficiently by practicing arborists working with street trees.

\section{MATERIAL AND METHODS}

To assess the establishment of street trees in Greater Melbourne, and to investigate potential causes of poor establishment, a survey was conducted during late spring and summer, using criteria relevant to the establishment of 21 different tree species of various age and size, grown as street trees in a number of municipalities. A total of 510 street trees were surveyed (Table 1) in the cities of Melbourne, Port Phillip, and Whittlesea, all of which fall within the area of Greater Melbourne, Victoria, Australia. The trees had been planted for periods of between 12 and 120 months, and both root and stem systems were investigated. Because the trees were of different ages, they ranged in height from two meters for the most recently planted trees to four meters for the oldest trees. All of the samples represent complete planting cohorts-no trees had been removed or replaced prior to this survey.

To assess root establishment, appropriate depth of planting and the presence or absence of trunk movement at ground level as measured by the Burnley Method were recorded. In this study, because tree height varied with the time since planting with older trees being taller, the Burnley Method was usually applied at a height of 1.2-2 $\mathrm{m}$ above ground level and the trees were moved through an arc of 500 $\mathrm{mm}$ backwards and forwards and/or side-toside. To assess successful canopy establishment, shoot tip extension, canopy dieback, presence of epicormic shoots or codominant stems, and the occurrence of trunk damage and sunscald injury were recorded. The data collected included details of location, the species, and the dates of planting, as obtained from the relevant municipal authorities, which allowed calculation of the time in the ground since transplant.

At the time of inspection, each tree was assessed for the following:

- Percentage of canopy dieback and chlorosis, which was assessed by a visual appraisal of the canopy as a percentage to the nearest $10 \%$. For deciduous trees not yet in foliage, canopy dieback was estimated by the percentage (again to the nearest $10 \%$ ) of dead or desiccated branches and buds. If there was $100 \%$ 
Table 1. Location, species, and number of trees of each species surveyed.

\begin{tabular}{lll}
\hline Species & Number of trees & Species \\
\hline (1) Angophora costata & 37 & (1) Pyrus calleryana \\
(1) Betula sp. & 11 & (1) Tristaniopsis laurina \\
(1) Brachychiton acerifolia & 2 & (1) Ulmus hollandica \\
(1) Celtis australis & 30 & (1) Ulmus procera \\
(1) Corymbia citriodora & 3 & (1) Waterhousia sp. \\
(1) Corymbia maculata & 89 & (1) Schinus molle \\
(1) Eucalyptus scoparia & 17 & (2) Acer buergerianum \\
(1) Eucalyptus spp. & 5 & (2) Brachychiton acerifolia \\
(1) Hymenosporum flavum & 5 & (3) Cupressus sempervirens \\
(1) Jacaranda mimosifolia & 8 & (3) Olea europaea \\
(1) Platanus $\times$ acerifolia & 40 & (3) Platanus $\times$ acerifolia \\
(1) Populus canadensis & 4 &
\end{tabular}

Note: 1 = City of Melbourne; 2 = City of Port Phillip; 3 = City of Whittlesea.

canopy dieback and no shoot extension, the tree was recorded as dead.

- Trunk condition, which took into account the presence of lignotuberous and epicormic shoots, sunscald, co-dominant leaders, damage to the bark/trunk, and vandalism.

- The soil around the root crown of each tree was cleared in order to assess planting depth. If the root crown was too deep (>100 $\mathrm{mm}$ below the site soil level) or soil was mounded around and up the trunk (>100 $\mathrm{mm}$ above the root ball soil level), then its planting was recorded as "too deep."

- Trunk movement, using the Burnley Method, and assessed as "movement" or "no movement. Since the soil and mulch around the root crown had been cleared away from the trunk to assess the depth of planting, any movement below ground level is readily observed.

- The measurement of tip extension involved measuring one of each of a north-, south-, west-, and east-facing shoot. The selected shoots were healthy terminals of a major shoot growing in that direction and were measured at a consistent height of between 1.5 to $2.1 \mathrm{~m}$ from the ground. Measurement was with a ruler and was done for the current season's growth, and where possible, the previous season's. Deciduous trees not yet in leaf had tip extension measured on the previous season's growth. Mean tip extension was calculated for each tree.

Having used scatterplots to check that data approximated a normal distribution, the data gathered for movement in the ground, plant- ing depth, and sunscald were subjected to a two-sample t-test to determine whether there were any significant differences $(P<0.05)$ in tip extension for trees identified as positive for these characteristics compared to trees that were not. Good tip extension was considered to be indicative of better tree establishment.

A Pearson correlation was used to further analyze data on tip extension and canopy dieback in Platanus $\times$ acerifolia. The analysis was undertaken to determine whether the significantly decreased tip extension that correlated with the high incidence of sunscald was also correlated with canopy dieback.

\section{RESULTS}

The results of the survey (Table 2) demonstrated that for the aboveground assessment of the trees, there was a low incidence (5\%) of codominant stems among the trees surveyed and that trunk damage affected $8 \%$ of the surveyed cohort. The presence of epicormic shoots in the canopy of $12 \%$ of the trees and sunscald damage to $13 \%$ of the tree trunks were more common occurrences. In relation to assessing indicators of root system establishment, the survey revealed that $42 \%$ of trees were moving the ground. It also showed that $12 \%$ of trees had been planted too deeply. That trees planted 12 months or less in the ground showed movement at or below the soil surface was to be anticipated, as recently planted young trees may take a growing season or two before they become stable (Table 3). However, it is of interest that $24 \%$ of trees planted for 40 and 44 months still exhibited trunk movement. 
Table 2. Tree species, number of trees surveyed, and the number of trees exhibiting the conditions used as criteria for tree establishment.

\begin{tabular}{|c|c|c|c|c|c|c|c|c|}
\hline Species & $\begin{array}{l}\text { Months after } \\
\text { planting }\end{array}$ & $\begin{array}{l}\text { Number } \\
\text { of trees }\end{array}$ & $\begin{array}{l}\text { Trunk } \\
\text { movement }\end{array}$ & $\begin{array}{l}\text { Trunk } \\
\text { damage }\end{array}$ & $\begin{array}{l}\text { Epicormic } \\
\text { shoots }\end{array}$ & Sunscald & Codominance & $\begin{array}{l}\text { Planted } \\
\text { too deep }\end{array}$ \\
\hline Acer buergerianum & 40 & 8 & 0 & & 8 & 4 & & \\
\hline Angophora costata & 12 & 37 & 19 & 3 & 1 & 5 & 4 & 8 \\
\hline Betula sp. & 120 & 11 & 1 & 3 & 3 & & 2 & \\
\hline Brachychiton acerifolia & 12 & 2 & 1 & & & & & \\
\hline Brachychiton acerifolia & 44 & 10 & 8 & & & & & \\
\hline Celtis australis & 3 & 2 & 2 & & & & & \\
\hline Celtis australis & 12 & 28 & 16 & & 2 & 1 & 5 & \\
\hline Cupressus sempervirens & 40 & 40 & 7 & 9 & & & 1 & 5 \\
\hline Corymbia citriodora & 12 & 3 & 1 & & & & & \\
\hline Corymbia maculata & 12 & 89 & 64 & 10 & 18 & & 8 & 36 \\
\hline Eucalyptus scoparia & 12 & 17 & 9 & & 3 & 4 & 1 & \\
\hline Eucalyptus spp. & 12 & 5 & 3 & & & & & \\
\hline Hymenosporum flavum & 12 & 5 & 2 & & & & & \\
\hline Jacaranda mimosifolia & 12 & 8 & 5 & & & & & \\
\hline Olea europaea & 40 & 66 & 16 & 3 & 2 & & & 13 \\
\hline Platanus $\times$ acerifolia & 12 & 40 & 10 & & 1 & 14 & & \\
\hline Platanus $\times$ acerifolia & 40 & 38 & 7 & 2 & 4 & 27 & & \\
\hline Populus canadensis & 12 & 4 & 4 & & & & & \\
\hline Pyrus calleryana & 12 & 37 & 10 & 3 & 8 & 9 & & \\
\hline Schinus molle & 12 & 22 & 6 & & 2 & & & \\
\hline Tristaniopsis laurina & 12 & 19 & 19 & 1 & 1 & & & \\
\hline Ulmus hollandica & 12 & 7 & 2 & 1 & 3 & & & \\
\hline Ulmus procera & 12 & 3 & 2 & 1 & & & & \\
\hline Waterhousia sp. & 120 & 9 & 0 & 6 & 5 & & 4 & \\
\hline Total (number) & & 510 & 214 & 42 & 61 & 64 & 25 & 62 \\
\hline Total (\%) & & & 41.96 & 8.23 & 11.96 & 12.55 & 4.9 & 12.16 \\
\hline
\end{tabular}

Table 3. Occurrence of trunk movement for different periods of time for all species after planting.

\begin{tabular}{llll}
\hline $\begin{array}{l}\text { Months after } \\
\text { planting }\end{array}$ & $\begin{array}{l}\text { Number } \\
\text { of trees }\end{array}$ & $\begin{array}{l}\text { Trunk } \\
\text { movement }\end{array}$ & $\begin{array}{l}\text { Trunk } \\
\text { movement (\%) }\end{array}$ \\
\hline 3 & 3 & 2 & 66.00 \\
12 & 325 & 173 & 53.23 \\
$40-44$ & 162 & 38 & 23.46 \\
120 & 20 & 1 & 5.00 \\
Total & 510 & 214 & \\
\hline
\end{tabular}

The number of trees of each species surveyed, their length of time in the ground, and the number of individuals exhibiting conditions that might affect, or be indicative of, the success or otherwise of their establishment process, are shown in Table 2. Data in the columns for trunk movement, sunscald, and trees planted too deep indicate the number of trees with these conditions. Figures in the columns for damage, epicormic shoots, and co-dominance are the number of occurrences of these conditions. Individual trees may show one or more of the conditions surveyed. The total number of trees displaying symptoms and the rate of occurrence of symptoms are given at the bottom of each column.

Those trees that exhibited high values for trunk movement and were recorded as being planted too deep and having sunscald (Table 2) were fur- ther investigated. Their tip-extension averages were tabulated and analyzed using a two-sample t-test, with significant difference at $P<0.05$, to see whether trunk movement, deep planting, or trunk sunscald reduced annual tip extension as an indicator of reduced canopy growth. Samples from the survey with high percentages of canopy dieback present were graphed against tip-extension measurements (Figure 1), and where tip extension was reduced, there was increased canopy dieback.

Table 4 lists those species where a large number of trees were assessed as showing trunk movement. Tip extension was measured for the current season's growth (one year), and where possible, the previous season (two years). The data show that Angophora costata, Corymbia maculata, and Pyrus calleryana had significantly less tip extension $(P<0.05)$ where trunk movement occurred. Platanus $\times$ acerifolia, after 40 months in the ground, had significantly less tip extension $(P<0.05)$ for the two previous season's growth where trunk movement was present.

The data for those species where a large number of trees were planted too deep (Table 2) showed that of the 89 Corymbia maculata surveyed, 36 trees were planted too deeply and exhibited 
trunk movement (Table 5). Their tip extension was significantly less $(P<0.05)$ than those that were planted at the correct depth, suggesting that deep planting has a significant deleterious effect on shoot-tip extension and ultimately tree establishment. For species where a large number of trees had sunscald recorded (Table 2), tip exten-

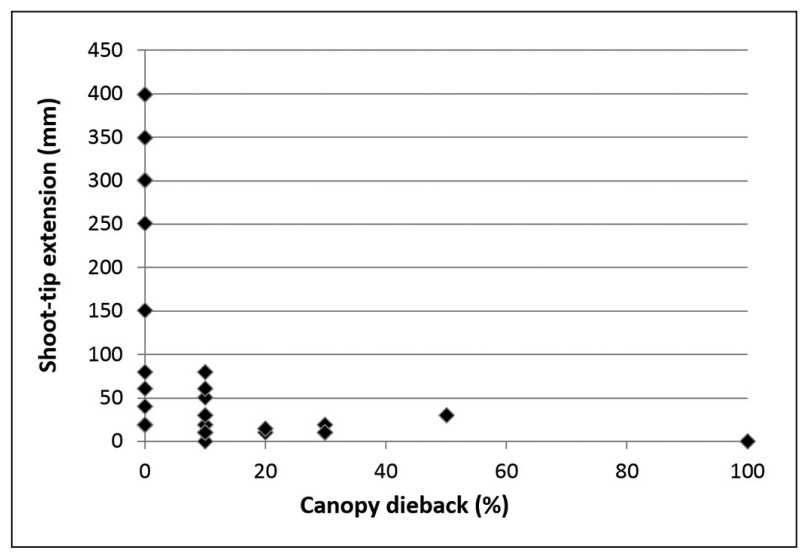

Figure 1. Percentage of canopy dieback and shoot-tip extension for Platanus $\times$ acerifolia (12 months after planting). sion was less for trees with sunscald (Table 6), but the difference was only significant for the Platanus $\times$ acerifolia cohort $(P<0.05)$ planted for 12 months. Further analysis of the data on canopy dieback and tip extension using Pearson Correlation for Platanus $\times$ acerifolia (Figure 1) trees planted 12 months earlier showed a significant $(P<0.05)$ relationship between the two measures.

\section{DISCUSSION}

The aim of this research was to evaluate the use of selected indicators of successful establishment of advanced tree stock, planted as urban street trees, which might prove practical in allowing arborists and urban tree managers to determine whether street trees had established. Using the definition of establishment as the tree growing well by being of an acceptable height, having good canopy spread and density (assessed by measuring tip extension), and being stable in the ground two growing seasons after planting, the data indicate that no single assessment criterion

Table 4. Average tip extension of trees with and without trunk movement.

\begin{tabular}{|c|c|c|c|c|c|}
\hline Species & $\begin{array}{l}\text { Months after } \\
\text { planting }\end{array}$ & $\begin{array}{l}\text { Number } \\
\text { of trees }\end{array}$ & $\begin{array}{l}\text { No. of trees with } \\
\text { trunk movement }\end{array}$ & $\begin{array}{l}\text { Average tip extension } \\
\text { of affected trees }(\mathrm{mm})\end{array}$ & $\begin{array}{l}\text { Average tip extension } \\
\text { of non-affected trees }(\mathrm{mm})\end{array}$ \\
\hline Angophora costata & 12 & 37 & 19 & $44^{z}$ & 67 \\
\hline Brachychiton acerifolia & 44 & 10 & 8 & $\begin{array}{l}1 \mathrm{yr}=112 \\
1 \mathrm{yr}=72\end{array}$ & $\begin{array}{l}2 \mathrm{yr}=119 \\
2 \mathrm{yr}=102\end{array}$ \\
\hline Celtis australis & 12 & 28 & 16 & 104 & 81 \\
\hline Corymbia maculata & 12 & 89 & 64 & $39^{z}$ & 52 \\
\hline Eucalyptus scoparia & 12 & 17 & 9 & 104 & 84 \\
\hline Olea europaea & 40 & 66 & 16 & 201 & 190 \\
\hline Platanus $\times$ acerifolia & 12 & 40 & 10 & 126 & 110 \\
\hline Platanus $\times$ acerifolia & 40 & 38 & 7 & $\begin{array}{l}1 \mathrm{yr}=219^{\mathrm{z}} \\
2 \mathrm{yr}=259\end{array}$ & $\begin{array}{l}1 \mathrm{yr}=294^{\mathrm{z}} \\
2 \mathrm{yr}=278\end{array}$ \\
\hline Pyrus calleryana & 12 & 37 & 10 & $15 z$ & 34 \\
\hline
\end{tabular}

${ }^{z}$ Measurements with significant difference $(P<0.05)$, using a two-sample t-test.

Table 5. Average tip extension of trees planted too deep.

\begin{tabular}{lllll}
\hline Species & $\begin{array}{l}\text { Months after } \\
\text { planting }\end{array}$ & $\begin{array}{l}\text { Number } \\
\text { of trees }\end{array}$ & $\begin{array}{l}\text { No. of trees } \\
\text { planted too deep }\end{array}$ & $\begin{array}{l}\text { Average tip extension } \\
\text { of affected trees (mm) }\end{array}$ \\
\hline Angophora costata & 12 & 37 & 7 & 55 \\
Corymbia maculata & 12 & 89 & 36 & $32^{z}$ \\
Olea europaea & 40 & 66 & 13 & 210 \\
\hline
\end{tabular}

${ }^{\mathrm{z}}$ Measurements with significant difference $(P<0.05)$, using a two-sample t-test. 
could be used as an indicator of either successful or unsuccessful street tree establishment.

The study is limited by the fact that data were obtained from trees that had been planted by others in different places over a ten-year period. For some species, the number of specimens available for assessment was small, and the Burnley Method is both a crude and indirect way of determining root establishment. However, by combining the results from several criteria, a more useful indication of establishment might be available for urban tree managers. Three criteria-appropriate annual shoot-tip extension, trunk movement (using the Burnley Method), and percentage of canopy dieback-could be useful measures of whether street trees were well or poorly established.

\section{Trunk Movement}

The results summarized in Table 4 show that 12 months after planting, the percentage of trees that were still moving in the ground ranged from $25 \%$ to $72 \%$, with an average of $48 \%$. After a decade in the ground, only one of eleven Betula specimens (9\%) was still moving. After 40-44 months, 80\% of Brachychiton acerifolia (8 of 10 trees), 24\% of Olea europaea (16 of 66 trees), 18\% of Platanus $\times$ acerifolia ( 7 of 38 trees), and $17 \%$ of Cupressus sempervirens ( 7 of 40 trees) were moving in the ground. This has implications not only for tree establishment and management, but also raises issues of risks to property and people. All specimens of Acer buergerianum and Waterhousia floribunda were stable in the ground.

To supply essential growth requirements (e.g., water and nutrients) to the canopy, a spreading and established root system is necessary (Kozlowski et al. 1991; Watson 1992). Tip extension results from the meristematic activity at the shoot apices where growth requirements are high (Kramer and Kozlowski 1979; Ridge 1991). A lack of water and nutrients can mean reduced growth for following seasons (Patterson 1977), as appeared to be the case of Platanus $\times$ acerifolia 40 months post-transplanting.

The use of advanced stock has the disadvantage of an unbalanced root:shoot ratio, which may result in dehydrated shoots, low rates of transpiration, and decreased growth (Kozlowski et al. 1991). There are also risks of root deformities, such as circling or kinked roots, from inappropriate nursery production systems or poor planting technique, which can limit root growth and lead to poor tree stability (Moore 1985; Harris et al. 1999; Benedikz et al. 2005). While trunk movement in the ground is to be expected in the early months after planting, the more rapidly the roots can grow into the surrounding soil, enabling greater water absorption, the less stressed the tree is likely to be and the quicker its establishment (Kozlowski 1987; Whitcomb 1987; Watson 1992). A balanced root:shoot ratio is desired in street tree stock, so selecting good-quality tree stock and ensuring that the irrigation regime is suited to the size of the root plate of planted stock will enhance establishment.

A reduced internal distribution of photosynthate to a restricted tree root system, compared to unrestricted root growth, can lead to higher aboveground vegetative growth and reduced root growth, which can then lead to what appears to be a healthy tree at the aboveground level but which has a poor root system, and so the tree exhibits trunk movement (Richards and Rowe 1977; Moore 1985). The sites of active growth, such as root and shoot tips, are where photosynthate and solute requirements are highest (Kramer and Kozlowski 1979; Salisbury and Ross 1992). Extensive shoot growth by trees with restricted root systems may continue for some years after planting (Moore 1985; Rushforth 1987; Harris 1992), until the root system's capacity for the uptake of water and nutrients becomes limiting, which can result in rapid tree decline and death (Moore 1985).

\section{Depth of Planting}

Trees growing in the field or container prior to transplanting have grown roots under optimal or near-optimal conditions. When the tree is transplanted into a streetscape, and the depth of soil above the root system is suddenly increased, oxygen and moisture availability and the physical characteristics of the root zone are changed (Arnold et al. 2007; Day et al. 2009). After planting in the landscape, the irrigation regime must suit the tree's requirements. Container-grown stock require more frequent irrigation than established street trees. Root growth and regeneration are slowed or halted due to the limitations imposed by the growing environment when trees are planted too deeply 
and the root system cannot transport sufficient water and elements for growth to the meristematic regions of the shoot system (Kramer and Kozlowski 1979). Reduced tip extension in trees planted too deeply was to be expected and reflects the stresses that ensue from poor planting technique (Gilman and Grabosky 2004: Wells et al. 2006).

It is concerning that planting too deeply is still a common problem in an era where tree management practices have generally improved. Municipal planting specifications must be more clearly documented and enforced under street tree planting contracts. The resilience of deeply planted Olea europaea after 40 months after planting was notable. Even though the trees had been planted incorrectly, they were able to establish due to the capacity of Olea species to rapidly regenerate adventitious roots from the root crown (Rugini and Baldoni 2005; Day et al. 2009), which may also account for the success of transplanting large specimens of this species. Planting too deeply not only affects tree establishment, but may predispose affected trees to whole tree failure (windthrow) when they are mature (Smiley 2005; Day et al. 2009; Moore 2014).

\section{Canopy Dieback, Tip Extension, and Sunscald}

There is a relationship between canopy dieback and reduced root growth (Kozlowski 1971; Patterson 1976). Defoliation directly and adversely affects root growth because of reduced photosynthate availability and altered distribution of growth regulators (Moore 1998), while the root system supplies water, nutrients, and growth regulators ensuring healthy shoot growth (Kozlowski 1971; Watson 1992). Figure 1 compares tip extension with canopy dieback for Platanus $\times$ acerifolia (12 months post-transplant cohort). Tip extension was reduced where canopy dieback had occurred; generally, more extension occurred when canopy dieback was absent (Table 4), which supports the notion that reduced production of photosynthates from dieback-affected plants results in reduced growth.

While Figure 1 supports the notion that canopy dieback and shoot-tip extension are essentially different ways of measuring the same thing, but in opposite directions, there are differences. Canopy dieback measures overall canopy condition, while shoot-tip extension measures the growth of an individual shoot tip. While the two are clearly correlated, Figure 1 shows that while a general assessment of canopy dieback is a rather blunt instrument of measurement, shoot-tip measurement is more nuanced. While the former is more commonly used and is a quicker and therefore cheaper form of assessment, measuring shoot-tip extension allows for comparison between seasons in a way that dieback does not. Furthermore, there were a number of trees that exhibited canopy dieback of $10 \%$ or less, but where shoot-tip extension was below $50 \mathrm{~mm}$.

While it is possible to have significant shoottip extension by some shoots in a canopy that is exhibiting symptoms of overall canopy dieback, the data support the use of tip extension as an indicator of general canopy condition. These data suggest that canopy dieback correlates with both reduced tree growth and the lower rate of successful establishment. Defoliation may directly and adversely affect growth for the current and following seasons (Patterson 1976). The data showed that some trees with no canopy dieback had little or no tip extension, which raises questions of stock quality, planting technique, irrigation, and maintenance (Gilman 1997). Such variability occurred for all species and may account for the different rates of growth and tree establishment under stressful urban conditions.

Data for the five species with a high percentage of sunscald are presented in Table 6 . The symptoms ranged from discoloration of the bark to severe damage, where bark and cambium tissues were dead, revealing the xylem tissue below. All five species had reduced tip extension where sunscald was recorded; however, this was only significant for Platanus $\times$ acerifolia (12 months post-transplant).

It is difficult to determine why sunscald occurred on some trees and not others of the same cohort. Kozlowski et al. (1991) reported sunscald damage to individual trees in a stand after thinning. Other factors that may contribute to the occurrence of sunscald include the heterogeneity of planting sites, the presence of nearby paving and other surfaces, poor postplanting maintenance, and the variable irrigation regimes applied to transplanted trees (Roppolo and Miller 2001). It was noted that symptoms of sunscald were often on the north and west 
Table 6. Average tip extension of trees with and without sunscald.

\begin{tabular}{|c|c|c|c|c|c|}
\hline Species & $\begin{array}{l}\text { Months after } \\
\text { planting }\end{array}$ & $\begin{array}{l}\text { Number } \\
\text { of trees }\end{array}$ & $\begin{array}{l}\text { No. of trees } \\
\text { with sunscald }\end{array}$ & $\begin{array}{l}\text { Average tip extension } \\
\text { of affected trees }(\mathrm{mm})\end{array}$ & $\begin{array}{l}\text { Average tip extension } \\
\text { of non-affected }(\mathrm{mm})\end{array}$ \\
\hline Acer buergerianum & 40 & 8 & 4 & $\begin{array}{l}1 \mathrm{yr}=37 \\
1 \mathrm{yr}=83\end{array}$ & $\begin{array}{l}2 \mathrm{yr}=109 \\
2 \mathrm{yr}=161\end{array}$ \\
\hline Eucalyptus scoparia & 12 & 17 & 4 & 57 & 106 \\
\hline Platanus $\times$ acerifolia & 12 & 40 & 14 & $50^{z}$ & 160 \\
\hline Platanus $\times$ acerifolia & 40 & 38 & 27 & $\begin{array}{l}1 \mathrm{yr}=276 \\
2 \mathrm{yr}=238\end{array}$ & $\begin{array}{l}1 \mathrm{yr}=290 \\
2 \mathrm{yr}=290\end{array}$ \\
\hline Pyrus calleryana & 12 & 37 & 9 & 21 & 31 \\
\hline
\end{tabular}

${ }^{\mathrm{z}}$ Measurements with significant difference $(P<0.05)$ using a two-sample t-test.

aspects of the trunk where sun exposure was greatest, which is consistent with the conclusions of Roppolo and Miller (2001), who recommended that the compass-bearing of injury should be included as part of the definition of sunscald. Despite Greater Melbourne experiencing summers where temperatures regularly exceed $40^{\circ} \mathrm{C}$, this is the first study to record the incidence of sunscald on urban trees in Australia.

\section{CONCLUSION}

This research investigated six practical criteria for determining whether street trees had established well or poorly. The research found that three of these criteria-tip extension, trunk movement in the root ball, and percentage of canopy diebackmight provide useful data to inform arboricultural management decisions about whether urban street trees have successfully or poorly established in the landscape. The measurement and comparison of tip extension proved to be a realistic and practical measure of tree growth. Trunk movement indicated poor establishment of the root system (and may be indicative of root system deformity), while canopy dieback was an indicator of the tree's poor health. All three criteria can be easily and quickly applied and do not require specialist or expensive equipment. The methods can also be readily adapted to other regions of the world and provide useful tools for future urban tree practice.

The research revealed that a large number of trees had not successfully established as measured by trunk movement, which may indicate poor quality stock, poor planting technique, or poor post-transplant maintenance $40-44$ months after planting. Further research into the causes and long- term consequences of trunk movement would seem to be worthwhile. The Burnley Method used in this research is a crude measure of root establishment, and further work to improve testing of root establishment is warranted. Canopy dieback may indicate insufficient irrigation and/or poor weed and competition control. The occurrence of sunscald might be reduced through more careful selection of stock and appropriate irrigation, but further research is required to identify both the extent and severity of sunscald injury under Australian climatic conditions on a wide range of native and exotic tree species.

\section{LITERATURE CITED}

Arnold, M.A., G.V. McDonald, D.L. Bryan, G.C. Denny, W.T. Watson, and L. Lombardini. 2007. Below-grade planting adversely affects survival and growth of tree species from five different families. Arboriculture \& Urban Forestry 33:64-69.

Benedikz, T., F. Ferrini, J.L. Garcia-Valdecantos, and M-L. Tello. 2005. Plant Quality and Establishment. pp. 231-256. In: C. Konijnendijk, K. Nilsson, T. Randrup, and J. Schipperijn (Eds). Urban Forests and Trees. Springer, Berlin, Germany. 520 pp.

Bühler, O., P. Kristoffersen, and S. Ugilt Larsen. 2007. Growth of street trees in Copenhagen with emphasis on the effect of different establishment concepts. Arboriculture \& Urban Forestry. 33:330-337.

Day, S.D., G. Watson, P.E. Wiseman, and J.R. Harris. 2009. Causes and consequences of deep structural roots in urban trees: From nursery production to landscape establishment. Arboriculture \& Urban Forestry 35:182-191.

Gilman, E.F., 1997. Trees for Urban and Suburban Landscapes. Delmar Cengage Learning, Boston, Massachusetts, U.S. 662 pp.

Gilman, E.F., and J. Grabosky. 2004. Mulch and planting depth affect live oak (Quercus virginiana Mill.) establishment. Journal of Arboriculture 30:311-317.

Gilman, E.F., C. Harchick, and M. Paz. 2010. Effect of tree size, root pruning, and production method on establishment of Quercus virginiana. Arboriculture \& Urban Forestry 36:183-190.

Grossnickle, C.S. 2005. Importance of root growth in overcoming planting stress. New Forests 30:273-294. 
Harris, R.W. 1992. Root-shoot ratios. Journal of Arboriculture 18:39-41.

Harris, R.W., J.R. Clark, and N.P. Matheny. 1999. Arboriculture. Prentice Hall, New Jersey, U.S.

Kenney, W.A., P.J.E. van Wassenaer, and A.L. Satel. 2011. Criteria and indicators for strategic urban forest planning and management. Arboriculture and Urban Forestry 37:108-117.

Kozlowski, T.T. 1971. Growth and Development of Trees 2. Academic Press, New York, New York, U.S. 514 pp.

Kozlowski, T.T. 1987. Soil moisture and absorption of water by tree roots. Journal of Arboriculture 13:39-46.

Kozlowski, T.T., P.J. Kramer, and S.J. Pallardy. 1991. The physiological ecology of woody plants. Academic Press, San Diego, California, U.S.

Kramer, P.J., and T.T. Kozlowski. 1979. Physiology of woody plants. Academic Press, San Diego, California, U.S.

Moore, G.M. 1985. Getting to the roots of the problem. The International Plant Propagators Society. Combined Proceedings 35:105-111.

Moore, G.M. 1990. Tree care for the home gardener. Lothian Publishing, Melbourne, Australia. 64 pp.

Moore, G.M. 1997. Tree biology and successful tree establishment pp. 8-16. In: K.D. Smith (Ed.). Trees - roots - soils: Managing the interaction. Centre of Urban Horticulture, Melbourne, Australia.

Moore, G.M. 1998. Tree growth regulators: Issues of control, matters of management. Journal of Arboriculture 24:10-18.

Moore, G.M. 2014. Windthrown tree: Storms or management? Arboriculture \& Urban Forestry 40:53-69.

Moore, G.M. 2015. Managing dormant buds as assets: Epicormic shoots. Arborist News 24(2):50-53

Patterson, J.C. 1976. Soil compaction and its effects upon urban vegetation. Better trees for urban landscapes. USDA General. Technical. Report, NE22. Cited in: K.D. Smith. 1992. Root growth in difficult conditions - Between a rock and a hard place! In: K.D. Smith (Ed.). Trees - roots - soils: Managing the interaction. Centre of Urban Horticulture, Melbourne, Australia.

Patterson, J.C. 1977. Soil compaction-Effects on urban vegetation. Journal of Arboriculture 3:161-167.

Richards, D., and R.N. Rowe. 1977. Effects of root restriction, root pruning and 6-benzylaminopurine on the growth of peach seedlings. Annals of Botany 41:729-740.

Ridge, I. 1991. Plant physiology. Hodder and Stoughton, London, UK.

Roppolo, D.J., and R.W. Miller 2001 Factors predisposing urban trees to sunscald. Journal of Arboriculture 27:246-254.

Rugini, E., and L. Baldoni. 2005. Olea europaea olive. In: R.E. Litz (Ed.). Biotechnology of fruit and nut crops. CABI Publishing.

Rushforth, K. 1987. The Hillier book of tree planting and management. David and Charles, London, UK.

Ryder, C., and G.M. Moore. 2013 The arboricultural and economic benefits of formative pruning street trees. Arboriculture \& Urban Forestry 39:17-23.

Salsibury, F.B., and C.W. Ross. 1992. Plant Physiology, fourth edition. Wadsworth Publishing, California, U.S. 682 pp.

Sinnett, D.J., D. Poole, and T.R. Hutchings. 2008. A comparison of cultivation techniques for successful tree establishment on compacted soil. Forestry 81:663-679.
Smiley, E.T. 2005. Root collar excavations to improve tree health. pp. 49-50. In: Getting the Roots Right. The Morton Arboretum, Lisle, Illinois, U.S.

Strouts, R.G., and T.G. Winter. 1994. Diagnosis of ill-health in trees. Forestry Commission, London, UK.

Struve, D.K. 1993. Street tree establishment. In: G.W. Watson and D. Neely (Eds.). The Landscape Below Ground. International Society of Arboriculture, Champaign, Illinois, U.S. 222 pp.

Ward, J.S., M.P.N. Gent, and G.R. Stephens. 2000. Effects of planting stock quality and browse protection-type on height growth of northern red oak and eastern white pine. Forest Ecology and Management 127:205-216.

Watson, G.W. 1987. The relationship of root growth and tree vigor following transplanting. Journal of Arboriculture 11:97-104.

Watson, G.W. 1992. Tree planting from beginning to end. In: K.D. Smith (Ed.). Trees - roots - soils: Managing the interaction. Centre of Urban Horticulture, Melbourne, Australia.

Watson, G.W., G.K. Kupkowski, and K.G. von der Heide-Spravka. 1992. The effect of backfill soil texture and planting hole shape on root regeneration of transplanted green ash. Journal of Arboriculture 18:12-129.

Wells, C., K. Townsend, J. Caldwell, D. Ham, E.T. Smiley, and M. Sherwood. 2006. Effects of planting depth on landscape tree survival and girdling root formation. Arboriculture \& Urban Forestry 32:305-311.

Whitcomb, C.E. 1987. Establishment and maintenance of landscape plants. Lacebark Publications, Oklahoma, U.S. 638 pp.

\author{
M. Leers \\ Director Works and Services \\ Shire of Manjimup \\ 37-39 Rose Street \\ Manjimup, Western Australia, 6258 \\ Australia \\ G.M. Moore (corresponding author) \\ School of Ecosystem and Forest Sciences \\ University of Melbourne, Burnley \\ 500 Yarra Boulevard \\ Richmond, Victoria 3121 \\ Australia \\ P.B. May \\ School of Ecosystem and Forest Sciences \\ University of Melbourne, Burnley \\ 500 Yarra Boulevard \\ Richmond, Victoria 3121 \\ Australia
}


Résumé. Plusieurs facteurs peuvent influencer la réussite ou non de l'implantation d'arbres de rue, dont la sélection inappropriée de l'essence, la faible qualité des arbres choisis en pépinière, une mauvaise technique de plantation, une irrigation insuffisante, un contrôle insatisfaisant des mauvaises herbes et un entretien arboricole déficient. Les forestiers urbains ont besoin d'indicateurs fiables, précis et pratiques afin de déterminer le succès ou non des projets de plantation et ainsi influencer les décisions quant au retrait des tuteurs ou au maintien des programmes d'irrigation. La réussite de la plantation d'arbres de gros calibre en alignement a été étudiée sur la base d'un relevé de 510 arbres de 21 espèces différentes, gérées par trois municipalités de l'agglomération de Melbourne, en Australie.

Un arbre planté ne peut être considéré comme établi que lorsque le système racinaire partiel contenu dans la motte ou le système racinaire confiné dans un contenant de production s'est développé en un système racinaire étalé, utilisant l'humidité et les nutriments disponibles dans un plus grand volume de sol. Ainsi, un indicateur de l'expansion des racines dans un plus grand volume de sol est nécessaire, comme le sont les mesures de la croissance de la canopée, telles que la croissance de la pousse annuelle ou le dépérissement de la canopée. L'étude a évalué six facteurs indicateurs d'une reprise à succès ou non : à savoir, les arbres avaient-ils été plantés trop profondément, les arbres présentaient-ils un mouvement du tronc au niveau du sol ou sous la surface, exhibaient-ils des dommages, des signes d'insolation ou la présence de pousses adventives (gourmands) sur le tronc et finalement, la présence de tiges codominantes.

Les résultats ont démontré que les dommages au tronc (8\%) et la présence de tiges codominantes $(5 \%)$ se retrouvaient à une faible fréquence chez les arbres, tandis que la présence de pousses adventives $(12 \%)$ et de dommages reliés à l'insolation $(12,5 \%)$ était plus fréquente, enfin $12 \%$ des arbres avaient été plantés trop profondément et $42 \%$ des arbres étaient instables. Trois critères, la longueur de la pousse annuelle, le mouvement du tronc dans le sol et le pourcentage de dépérissement de la canopée, ont fourni des mesures utiles dans la détermination de la reprise fructueuse ou non des arbres d'alignement. Il s'agit de la première étude à avoir révélé une incidence élevée de dommages dus à l'insolation sur les arbres urbains australiens.

Zusammenfassung. Die erfolgreiche Etablierung von Straßenbäumen kann von einer Reihe von Faktoren beeinflusst werden, einschließlich der unangemessenen Auswahl von Pflanzengrundstock, schlechtem Unkrautkontrolle und nicht adäquater Pflege. Urbane Baumpfleger brauchen verlässliche, akkurate und praktische Indikatoren, ob Straßenbäume nun erfolgreich etabliert sind, um Entscheidungen zu fällen, wann die Baumschutzeinrichtungen abgebaut werden oder das Bewässern fortzusetzen ist. Die Etablierung von großformatig gepflanzten Straßenbäumen wird hier mittels einer Datenfassung von 510 Bäumen aus 21 Arten, die von drei Gemeinden im Großraum Melbourne verwaltet werden, untersucht.

Ein gepflanzter Baum nur dann als etabliert gesehen werden, wenn das partielle Wurzelsystem im Wurzelballen oder das begrenze Wurzelsystem in einem Pflanzencontainer sich durch die Verwendung von Feuchtigkeit und vorhandenen Nährstoffen aus einem größeren verfügbaren Bodenvolumen in ein sich ausbreitendes Wurzelsystem entwickelt hat. Daher ist ein Indikator für Wurzelexpansion in größere verfügbare Bodenbereiche wichtig, so wie Messungen des Kronenzuwachses, Trieblängenwachstum oder Kronenabsterben. Die Datenerfassung untersuchte sechs Faktoren, die auf erfolgreiche oder dürftige Etablierung hinweisen: ob die Bäume zu tief gepflanzt wurden, ob sich die Bäume im Pflanzloch bewegt haben, Schaden am Stamm, Sonnenbrand am Stamm, Stammaustriebe und Bildung von Nebenstämmen.

Die Ergebnisse demonstrierten, dass Stammschäden (8\%) und kodominante Stämme (5\%) in niedrigen Raten bei den Bäumen auftraten, aber das Auftreten von Stammaustrieben (12\%) und Sonnenbrand (12,5\%) war häufiger und $12 \%$ der Bäume waren zu tief gepflanzt und $42 \%$ der Bäume waren instabil. Drei Kriteria - Trieblängenwachstum, Stammbewegung im Boden und der Prozentsatz von Kronenabsterben - lieferten nützliche Hinweise, ob die untersuchten Bäume sich gut oder schlecht am Standort etabliert hatten. Das ist die erste Studie an Straßenbäumen in Australien, die einen Nachweis von hohem Auftreten von Sonnenbrandverletzungen am Stamm verzeichnet.

Resumen. arios factores pueden influir en el establecimiento exitoso del árbol urbano, incluyendo la pésima selección, mala calidad de las existencias, deficiente técnica de plantación, riego insuficiente, control inapropiado de las malas hierbas y el mantenimiento inadecuado. Los administradores de árboles urbanos necesitan indicadores confiables, precisos y prácticos de si los árboles se han establecido con éxito para con esto informar las decisiones de remoción de soportes de los árboles o continuar los regímenes de riego. Se investigó el establecimiento de árboles plantados como stock de gran formato utilizando una encuesta de 510 árboles de 21 especies manejadas por tres municipalidades en Greater Melbourne, Australia.

Un árbol plantado solo puede considerarse establecido cuando el sistema de raíces parciales en el cepellón o las raíces confinadas en un contenedor se ha convertido en un sistema de raíces esparcidas, que utiliza la humedad y los minerales disponibles a través de un mayor volumen de suelo. Por lo tanto, es necesario un indicador de la expansión de la raíz hacia el suelo de mayor volumen, como son las medidas del crecimiento del dosel, la longitud del rebrote o la muerte regresiva de la copa. La encuesta evaluó seis factores indicativos de establecimiento exitoso o deficiente: si los árboles habían sido plantados demasiado profundamente, si los árboles exhibieron movimiento del tronco en o debajo de la superficie del suelo, el daño al tronco, lesión del tronco por el sol, presencia de brotes epicórmicos en el tronco y si había tallos co-dominantes.

Los resultados demostraron que el daño del tronco (8\%) y los tallos codominantes (5\%) ocurrieron a tasas bajas en los árboles, pero la presencia de brotes epicórmicos (12\%) y daño solar de la corteza (12.5\%) fue más común, y $12 \%$ de los árboles habían sido plantados demasiado profundamente y el $42 \%$ de los árboles eran inestables. Tres criterios: la longitud del brote, el movimiento del tronco en el suelo y el porcentaje de la muerte regresiva del dosel proporcionaron medidas útiles de si los árboles se evaluaron como buenos o pobremente establecidos. Este es el primer estudio en registrar una alta incidencia de daños por quemaduras solares de árboles urbanos en Australia. 